\title{
Female Journalists More Likely To Leave Newspapers
}

by Scott Reinardy

\section{A survey of 715 U.S. newspaper journalists reveals women report higher levels of exhaustion and lower levels of professional efficacy than do men. Among women 27 and younger, 30 percent say they intend to leave the field.}

$\mathrm{I}_{\mathrm{n}}$

a page 2 Columbia Missourian editorial, the headline asked, "Should a girl have brains?" While the editorial emphasized the need for women to pursue their college ambitions, in part it said:

To succeed amid the fierce competitions of the world she needs all the strength of character, all the development of mind that the most carefully arranged curriculum can give. ${ }^{1}$

The editorial was published in correspondence with the increasing enrollment of women at the University of Missouri in 1908. Two weeks later, Mary Paxton, the first woman to graduate from the MissouriSchool of Journalism-the nation's first school of journalism-was elected secretary of the Press Club. ${ }^{2}$

In the 100 years since those occurrences at the University of Missouri, women in the workplace, and more specifically journalism, have made tremendous strides. In 2008, women accounted for 37 percent of U.S. journalists, ${ }^{3}$ a dramatic increase from the 20.3 percent in $1971^{4}$ and 7.3 percent in $1900 .{ }^{5}$ Also, at nearly 64 percent women continued to be the overwhelming majority enrolling in

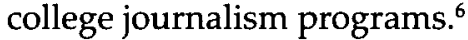

But the advancements of women in journalism continue to lag behind the overall U.S. workforce. Overall, in 2005 women accounted for 46.3 percent of the

Reinardy is an assistant professor in the William Allen White School of Journalism and Mass Communication at the University of Kansas. 
labor force. ${ }^{7}$ Meanwhile, while half of all people in management, professional or related occupations were women, ${ }^{8}$ only 24 percent of women occupied supervisory positions in journalism. ${ }^{9}$ As for pay, female journalists and the overall workforce were equal, but it was only 81 percent of what men earned..$^{10}$

Even with more opportunity and better pay than 35 years ago, women are less happy in their lives than they were in the 1970s. Analyzing data from the General Social Survey from 1972 to 2006, which includes more than 46,000 respondents, Stevenson and Wolfers ${ }^{11}$ reported that women have grown significantly less happy than men, but the researchers were unable to pinpoint the exact reasons for that decline. However, compared to men, women were less happy in their marriage (for those who were married) than men and less happy with the family financial situation. Also, while job satisfaction among men has remained relatively constant, it has declined for women. Stevenson and Wolfer wrote:

\section{Women may simply find the complexity and increased pressure in their modern lives to have come at the cost of happiness. ${ }^{12}$}

Loss of job satisfaction is nothing new among journalists. Weaver et al. reported that journalists who said they were "very satisfied" in their work has declined from 49 percent in 1971 to 33.3 percent in $2002 .{ }^{13}$ Of those "fairly satisfied" or "very satisfied" in the 2002 study, men accounted for 52.5 percent overall. ${ }^{14} \mathrm{Job}$ dissatisfaction might be indicative of intentions to leave journalism. More women (21 percent) said they intended to work outside of media within five years compared with men (16 percent). ${ }^{15}$ Overall, the main reasons for leaving the profession included low pay and job security ( 20 percent) and stress, burnout or poor working conditions ( 25 percent). ${ }^{16}$

With the changing media landscape that includes increased Internet competition and additional work responsibilities, the job of a journalist has become increasingly more difficult. Newsrooms have been designated "information centers, ${ }^{17}$ with the intent of providing online materials that include print-like stories, photographs, photo slideshows, informational graphics and video. Job cuts and diminishing resources have exasperated the burden for journalists and created additional stress. From 2005 to 2007, newspaper stocks fell 42 percent and Sunday circulation in 2007 continued its downward trend at 3.3 percent. ${ }^{18}$ And in 2008, it is estimated that more than 14,000 newspaper jobs had been eliminated. ${ }^{19}$

The stress for women is compounded by family issues, sexism, discrimination and the proverbial glass ceiling that limits professional prosperity. Female journalists are less likely to be married and have children than are men, ${ }^{20}$ and sometimes those wanting to have a child face discrimination. ${ }^{21}$ Studies have shown that for women with children, the child-care responsibilities primarily fall to them, which further hinder promotional opportunities ${ }^{22}$ Chambers, Steiner and Fleming wrote: "Women continue to suffer at the hand of unsympathetic 
bosses and unrealistically long hours."23

The stress identified by Chambers et al. can produce stressors, and over time, they can lead to burnout. Burnout is caused by stress that can lead to a depletion of emotional resources that affect a person's behavior and motivation ${ }^{24}$ Burnout can affect job performance, ${ }^{25}$ job satisfaction, ${ }^{26}$ work and family relationships, ${ }^{27}$ diminished productivity and employee turnover ${ }^{28}$

The purpose of this study is to examine burnout and job satisfaction among female newspaper journalists and the life issues, such as work-family conflict, perceived organizational support, role overload and job demands, which might affect burnout and satisfaction.

\section{Literature Review}

In 2005, the Centers for Disease Control listed journalism seventh among the most stressful jobs. ${ }^{29}$ However, minimal stress and burnout research has been conducted in this area. Journalists have said they have experienced stress-related health issues, ${ }^{30}$ said their jobs are "highly stressful,"31 and have admitted they are at risk for burnout, ${ }^{32}$ which were the result of stressors such as meeting newspaper deadlines, pressure to produce good work, low pay, media competition, long hours, implementing new technology and time away from family. ${ }^{33}$

Stressors accumulate, and how individuals react largely depends on their values, experiences and adaptability. A lone stressor can become compounded if the established support system fails. ${ }^{34}$ The stress of a reporter rushing to meet deadline is compounded when his or her computer malfunctions. When stress accumulates, the risk of burnout increases. Freudenberger and North wrote:

Over a short period of time, an 'overload of stress' produces a cranky, irritable person. Over a long period of time, that same daily stress places a demand on one's energy sources and produces a burned-out person. ${ }^{35}$

In an attempt to measure burnout among workers and their work, Maslach, Jackson and Leiter ${ }^{36}$ reconstructed the Maslach Burnout Inventory, ${ }^{37}$ which was originally developed to measure the relationship of workers and the people they work with (clients) in the health-care profession. The authors write,

The apparent need for a scale that measures burnout in other occupational groups prompted the development of the Maslach Burnout Inventory-General Survey. ${ }^{38}$

Schaufeli and Enzmann ${ }^{39}$ found that in 498 journal articles, 93 percent referred to the MBI. ${ }^{40}$

The authors write: 
Reinardy: Women Journalists More Likely to Leave Newspapers - 45

The MBI is now the most widely used and best validated instrument to measure burnout. ${ }^{41}$

In expanding the MBI in 1996 to include those outside the health care industry, Maslach, Jackson and Leiter created the MBI-General Survey (MBI-GS). The MBI-GS developers write,

The MBI-GS defines burnout as a crisis in one's relationship with work, not necessarily as a crisis in one's relationship with people at work. ${ }^{42}$

It measures burnout on three subscales: exhaustion, cynicism and professional efficacy. Exhaustion examines work fatigue, cynicism measures apathy or an aloof attitude toward work and professional efficacy focuses on an employee's expectations of his or her own work. ${ }^{43}$

The three-component MBI-GS rates a high degree of burnout if exhaustion and cynicism rate high scores and professional efficacy rates a low score. In the MBI-GS, cynicism represents dysfunctional coping, which means employees become indifferent and cynical about their work to create distance from the job's exhausting demands. While demonstrating a positive correlation with exhaustion, cynicism can also play a role in diminishing professional efficacy. ${ }^{44}$

In 1981 when Maslach and Jackson developed the MBI, they gave little consideration to stress, only writing that "chronic stress can be emotionally draining and poses the risk of 'burnout."' 45 In 2001, while re-examining burnout, Maslach, Schaufeli and Leiter said that after 20 years of MBI research burnout is "a psychological syndrome in response to chronic interpersonal stressors on the job." ${ }^{46}$ They also said exhaustion is the linchpin for stress that leads to burnout because a person will become overextended, and emotional and physical resources will become depleted.

For newspaper journalists, stress is an acceptable by product. Deadlines, competition, long and unusual hours and a demanding workload are commonplace stressors. Previous burnout studies on journalists have shown that younger, less experienced journalists suffer from higher rates of burnout than their older more experienced colleagues. ${ }^{47}$ Cook and Banks ${ }^{48}$ said the most "atrisk" journalists for burnout are young, new to the profession, multitasking on the copy desk and working at small newspapers. Typically they earn a belowaverage salary, intend to leave journalism and are less satisfied than their colleagues. In examining sports journalists, Reinard $\mathrm{y}^{49}$ reported that sports editors suffered higher rates of burnout than did sports writers and desk personnel, but overall none of the groups were experiencing high levels of burnout. Neither of those studies specifically examined the role of burnout among women, but other studies have done so by utilizing the MBI.

In examining occupational stress and burnout among 582 academic staff members at universities, Doyle and Hind $^{50}$ reported that women had higher levels of stress in their jobs. In fact, women rated higher in all 10 stressors presented 
in the study, including workload and "job interferes with personal life."

On the MBI, there were no significant differences between men and women on the subscales exhaustion and personal accomplishment, but women had lower scores on the depersonalization scale than did men. ${ }^{52}$ In essence, women had higher levels of stress but lower levels of burnout compared to men. Additionally, women reported more work pressure interfering with their personal lives, which Doyle and Hind conclude might be a reflection of "greater domestic responsibilities of women." 53

Other studies using the MBI have determined that women and men are generally equal in levels of exhaustion, but women have significantly lower levels of depersonalization, which would indicate lower levels of burnout. ${ }^{54}$ Also, some studies have shown that women experience lower levels of personal accomplishment than do men. ${ }^{55}$

Some studies found gender differences on the MBI's exhaustion scale. ${ }^{56}$ While Bekker et al. ${ }^{57}$ and Ahola et al. ${ }^{58}$ found higher levels of exhaustion in women, Greenglass et al. ${ }^{59}$ found the opposite, attributing the lower

levels to significantly more support from co-workers. This study will build upon previous work by examining burnout of female journalists working in newspaper newsrooms. Along with the MBI-GS, the measurements in this study include:

\section{Overall Job Satisfaction}

Cammann, Fichman, Jenkins and Klesh ${ }^{60}$ developed the Michigan Organizational Assessment Questionnaire to measure six models designed to provide 
information concerning the perceptions of individuals in an organization. The models examined general attitudes, which included the subcategory of job satisfaction.

Overall job satisfaction was developed "to provide an indication of the organization's members' overall affective responses to their jobs." ${ }^{11}$

\section{Perceived Organizational Support}

Eisenberger, Huntington, Hutchison and Sowa ${ }^{62}$ developed a scale that would measure employees' perceptions of organizational support (POS). Specifically, Eisenberger et al. wanted to examine an individual's dedication to an organization and the factors that might influence that dedication, such as how an organization treats an employee, and the perception and underlying motives of that treatment.

Since its development, more than 70 studies across a variety of disciplines have utilized POS measurement. ${ }^{63}$

\section{Work-Family Conflict}

Netemeyer, Boles and McMurrian ${ }^{64}$ established the work-family conflict measurement with the understanding that these conflicts lead to job dissatisfaction, burnout, job turnover and possibly work productivity.

Netemeyer et al. defined WFC as,

A form of interrole conflict in which the general demands of, time devoted to and strain created by the job interfere with performing family-related responsibilities. ${ }^{65}$

Stressors in the form of WFC lead to other issues such as job dissatisfaction and burnout, which in turn lead to a reduction in production and an increase in employee turnover. ${ }^{66}$

\section{Role Overload}

Beehr, Walsh and Taber ${ }^{67}$ examined the role of stress on individually valued aspects (job dissatisfaction, fatigue and tension) and organizational valued aspects (quantity of work, quality of work and work involvement). In differentiating between the role stressors of role overload and role conflict, Bucharach, Bamberger and Conley ${ }^{68}$ refined the role overload scale tested by Beehr et al. Bucharach et al. defined role overload as

...the professional's perception that he or she is unable to complete assigned tasks effectively due to time limitations (i.e., the conflict between time and organizational demands concerning the quantity of work to be done). ${ }^{69}$ 


\section{Job Demands}

Karasek $^{70}$ developed the job demand-control (JDC) measure to assess the effects of job stress on the physical health of workers. The seven-question scale examines job stressors and is based on two critical aspects: job demand (workload in terms of time pressure and role conflict) and job control (employees' ability to control his or her work activities).

\section{Research Questions and Hypotheses}

Using the MBI-GS and the measurements for overall job satisfaction, perceived organizational support, work-family conflict, role overload and job demands, this study will examine the following hypotheses and research question:

\section{RQ1}

Will there be differences between male and female journalists in overall job satisfaction, perceived organizational support, work-family conflict, role overload and job demands?

\section{H1}

Female journalists will report significantly higher levels of exhaustion on the MBI-GS scale than will men.

H2:

Female journalists will report significantly lower levels of professional efficacy on the MBI-GS scale than will men.

H3:

Women who said they intend to leave journalism will experience significantly higher levels of burnout on the MBI-GS scale than will women who said they did not intend to leave journalism.

H4:

Overall job satisfaction and perceived organizational support will have a positive affect in reducing burnout among female journalists.

H5:

Work-family conflict, role overload and job demands will have a negative affect in increasing burnout of female journalists. 
Reinardy: Women Journalists More Likely to Leave Newspapers - 49

\section{Method}

The Editor $\mathcal{E}$ Publisher International Yearbook ${ }^{71}$ was used to extract e-mail contacts at 1,452 U.S. daily newspapers. Most of the contacts were managing editors. An e-mail was then sent to the managing editors in January 2007, explaining the study and requesting the staff e-mail lists of their full-time newspaper employees. If e-mail addresses of managing editors were not available, the recruitment e-mail was sent to a general news mailbox.

Of the 1,452 e-mails, 338 were dead accounts. Of the remaining 1,114, some 74 newspaper representatives responded and provided access to their staffs' e-mail lists. From that list, a database of 2,791 journalists was established.

The 73-question survey consisted of six sections, including job relationship, job satisfaction, work and family life, job demands, social support and background. The "job relationship" section included the 16-question MBI-GS. The "job satisfaction" section included the three-question MOAQ job satisfaction scale, and nine-question perceived organizational support scale, which asked respondents to answer using a Likert-type scale $(1=$ strongly disagree to $7=$ strongly agree). The "work and family life" section included the five-question work-family conflict scale, which used a Likert-type scale $(1=$ strongly disagree to $7=$ strongly agree). The seven-question "job demands" section asked respondents to respond on a Likert-type scale $(1=$ never to $5=$ extremely often $)$. The "social support" section included the three-question role overload scale ( $1=$ definitely false to $4=$ definitely true). In the final section, "background," demographic information was collected, including gender, age, journalism experience, job title, race, newspaper circulation size, salary, marital status, parental responsibilities and work hours per week. Questions about newsroom staff reductions within the past year, online responsibilities, intentions to leave journalism and newspaper ownership group were included in this section as well.

In February 2007, 2,791 full-time newspaper journalists were sent an explanatory e-mail and a Web link to the voluntary and anonymous survey, which was made available on freeonlinesurvey.com. After discarding 120 dead e-mail accounts, the sample was reduced to 2,671 . The respondents received a reminder e-mail in March 2007.

Of the 2,671 journalists, 715 completed the survey for a response rate of 26.7 percent, which aligns with Web survey response rates in other studies. ${ }^{72}$

\section{Findings}

Mean substitution was implemented to replace missing values in the data set of 715 respondents, but no more than 3 percent of any variable was replaced.

Descriptive statistics determined respondents averaged 41.6 years old, had 17.8 years of journalism experience, earned an average of $\$ 48,497$, worked at a newspaper with an average circulation of 183,500 and worked on average 45.7 
hours per week. Women in this study averaged 38.6 years old, had 13.9 years of experience, earned on average $\$ 44,005$, worked at a newspaper with an average circulation of 176,737 and worked an average of 44.8 hours per week. Overall, a large majority of the respondents were Caucasian ( 90.9 percent), 57.6 percent were male, 59 percent were married and 49.7 percent had children. Of the women, 48 percent were married and 36.2 percent had children.

Independent sample t-tests were conducted to answer RQ1, which asked if there will be differences between men and women journalists in overall job satisfaction, perceived organizational support, work-family conflict, role overload or job demands. The results indicate that there were significant differences between men and women in three areas-perceived organizational support, role overload and job demands. There were significant differences ( $p$ $<.05$ ) between men and women in perceived organizational support, as men indicated high levels of POS than did women. There were also significant differences $(\mathrm{p}<.01)$ for job demand, as men indicated experiencing lower levels of job demand than did women. Additionally, there were significant differences $(\mathrm{p}<.01)$ in role overload, as men indicated lower levels of role overload than did women. There were no significant differences between the groups in job satisfaction or work-family conflict.

H1 hypothesized that female journalists would report higher levels of exhaustion on the MBI-GS scale than would men.

The independent sample $t$-test indicated significant differences $(p<.01)$ between the groups, with men reporting lower levels of exhaustion than did women. [See Table 1] On the MBI-GS scale, a mean score between 2.01 and 3.19 indicates an average level of exhaustion. So although there are differences between men and women, both rate "average" in terms of the amount of exhaustion they are experiencing. Nonetheless, H1 was supported.

H2 stated that female journalists will report significantly lower levels of professional efficacy on the MBI-GS scale than would men.

Independent sample t-tests were used to determine $\mathrm{H} 2$. There were significant differences $(p<.05)$ between the groups, as men reported higher levels of professional efficacy than did women [See

\section{Table 1}

Mean MBI-GS Scores Comparing Women and Men

$\begin{array}{lllll} & & E x & \text { Cyn } & P E \\ \begin{array}{llll}\text { Women } \\ (\mathrm{n}=286)\end{array} & \text { Mean } & 3.09 & 2.68 & 4.82 \\ & \text { SD } & 1.41 & 1.65 & 0.88 \\ \text { Men } & & & & \\ (\mathrm{n}=388) & \text { Mean } & 2.76 & 2.53 & 4.96 \\ & \text { SD } & 1.48 & 1.60 & 0.77\end{array}$

$E x=$ Exhaustion $;$ Cyn $=$ Cynicism $P E=$ Professional Efficacy $E E: 3.2$ and above $=$ high; $2.01-3.19=$ average; 2.00 and less $=$ low. Cyn: 2.20 and above $=$ high; 1.01-2.19 = average; 1 and less $=$ low. $P E: 5$ and above $=$ low; $4.01-4.99=$ average 4 and less $=$ high . 
Table 1] On the MBI-GS scale, a mean score between 4.01 and 4.99 indicate. "average" professional efficacy. So although $\mathrm{H} 2$ was supported, the difference between the groups was minimal.

\section{H3 stated that} women who said they intended to
Table 2

Mean MBI-GS Scores Comparing Women who Intend to Leave Journalism with Those who Don't Intend to Leave

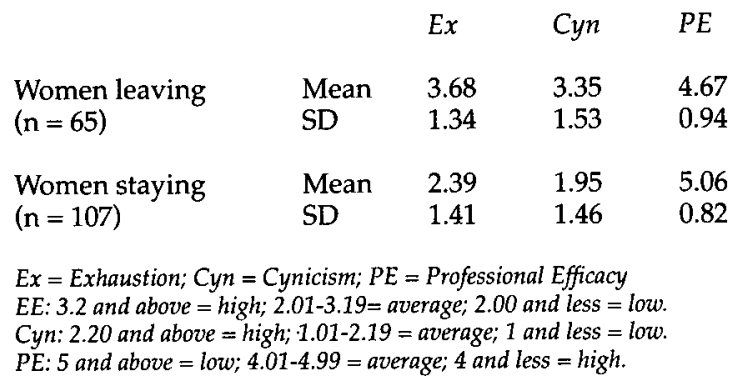

leave journalism would experience significantly higher levels of burnout than would those who said they did not intend to leave journalism.

An independent sample t-test determined that there were significant differences between the groups on all three MBI-GS subscales: exhaustion $t(170)=$ $5.90, \mathrm{p}<.001$; cynicism $t(170)=5.98$; professional efficacy $t(170)=-2.867$. Those intending to leave journalism reported higher levels of exhaustion and cynicism than those who did not intend to leave. Additionally, women who intended to leave journalism had significantly lower levels of professional efficacy than women who did not intend to leave. [See Table 2] To summarize, women who intended to leave journalism had higher levels of exhaustion and cynicism, and lower levels of professional efficacy, which means $\mathrm{H} 3$ was supported.

H4 stated that overall job satisfaction and perceived organizational support will have a positive affect in reducing burnout among female journalists.

When exhaustion was the dependent variable, job satisfaction and perceived organization support account for about 40 percent of the variance (adjusted $\mathrm{r}$ square $=40.1), F(2,280)=95.527, \mathrm{p}<.001$. Job satisfaction $[B=-.582, \mathrm{t}(280)=-9.25$, $\mathrm{p}<.001$ ]was a negative, significant predictor of exhaustion. Perceived organizational support $[B=-.076, \mathrm{t}(280)=-1.20, \mathrm{p}>.05]$ was not a significant predictor in this model. When cynicism was the dependent variable, job satisfaction and perceived organizational support accounted for about 55 percent of the variance (adjusted r-square $=55.4), \mathrm{F}(2,280)=176.336, \mathrm{p}<.001$. Job satisfaction $[B=-578$, $t(280)=-10.64, p<.001]$ and perceived organizational support $[B=-.221 \mathrm{t}(280)$ $=-4.06, \mathrm{p}<.001]$ were negative and significant predictors of cynicism. When professional efficacy was the dependent variable, job satisfaction and perceived organizational support accounted for about 23 percent of the variance (adjusted $\mathrm{r}$-square $=22.5), \mathrm{F}(2,280)=42.001, \mathrm{p}<.001$. Job satisfaction $[B=.312, \mathrm{t}(280)=$ $4.35, \mathrm{p}<.001]$ was a positive, significant predictor of professional efficacy, as 
was perceived organizational support $[B=.210, \mathrm{t}(280)=2.93, \mathrm{p}<.01]$. To summarize, exhaustion and cynicism have a negative correlation to job satisfaction, but only cynicism is negatively correlated to perceived organizational support. Also, job satisfaction and perceived organizational support have a positive correlation to professional efficacy. Thus, $\mathrm{H} 4$ was partially supported.

H5 stated that work-family conflict, role overload and job demands will have a negative affect in increasing burnout of female journalists.

When exhaustion was the dependent variable, work-family conflict, job demands and role overload accounted for about 30 percent of the variance (adjusted $\mathrm{r}$-square $=30.2), \mathrm{F}(3,269)=34.140, \mathrm{p}<.001$. Work-family conflict $[B=.337$, $t(269)=5.96, p<.001]$ was a positive and significant predictor of exhaustion, as was the job demands variable $[B=.232, \mathrm{t}(269)=2.91, \mathrm{p}<.01]$. Role overload was not a significant predictor of exhaustion in this model $[B=.074, \mathrm{t}(269)=$ $.93, \mathrm{p}>.05]$. When cynicism was the dependent variable, work-family conflict, job demands and role overload accounted for about 6 percent of the variance (adjusted $\mathrm{r}$-square $=6.2$ ), $\mathrm{F}(3,269)=4.983, \mathrm{p}<.01$. Only work-family conflict $[B$ $=.132, t(269)=2.05, \mathrm{p}<.05]$ was a positive and significant predictor of cynicism, while job demands $[B=.077, \mathrm{t}(269)=.85, \mathrm{p}>.05]$ and role overload $[B=.075$, $t(269)=.823, p>.05]$ were not. When professional efficacy was the dependent variable, work-family conflict, job demands and role overload accounted for about 4 percent of the variance (adjusted r-square $=.037, \mathrm{~F}(3,269)=4.501, \mathrm{p}<$ .01 . While work-family conflict $[B=-.186, \mathrm{t}(269)=-2.87, \mathrm{p}<.01]$ was a negative and significant predictor of professional efficacy, job demands $[B=.202, \mathrm{t}(269)=$ $2.21, \mathrm{p}<.05]$ was a positive and significant predictor of PE. Role overload was not a significant predictor of professional efficacy $[B=-.171, \mathrm{t}(269)=-1.89, \mathrm{p}>$ .05]. To summarize, the model of work-family conflict, job demands and role overload only had a partial, positive correlation with exhaustion and cynicism, and a partial, negative correlation with professional efficacy. Therefore, $\mathrm{H} 5$ was only partially supported, and although the relationships were significant, the correlations were weak.

\section{Conclusions}

The purpose of this study was to examine burnout and job satisfaction among female newspaper journalists and life issues, such as work-family conflict, perceived organizational support, role overload and job demands, which might affect burnout, and satisfaction. Some of the results of this study replicate previous results where women experienced more exhaustion on the MBI than did men, ${ }^{73}$ and lower levels of professional efficacy or personal accomplishment ${ }^{74}$ than did men.

With the MBI-GS, exhaustion examines fatigue, cynicism examines "indifference or a distant attitude toward work," and professional efficacy measures expectations and accomplishments. ${ }^{75}$ In their 2001 retrospective, Maslach, 
Schaufeli and Leiter ${ }^{76}$ contend that people experiencing exhaustion create distance by becoming indifferent or cynical. They argue that exhaustion and cynicism lead to a lack of efficacy. However, others argue that the subscales of the MBI (emotional exhaustion, depersonalization and personal accomplishment) must be treated as separate constructs. ${ }^{77}$ Lee and Ashford contend that personal accomplishment "develops largely independent of emotional exhaustion and depersonalization." ${ }^{78}$ That certainly could be the case in this study. While women in this study did not experience any more cynicism than did men, there were significant differences on the other two MBI-GS subscales.

Because the relationship between burnout and work-family conflict, job demands and role overload were not strong, it's difficult to determine exactly what is causing the levels of exhaustion and professional efficacy among female journalists. And although the relationships between job satisfaction and perceived organizational support in diminishing burnout were strong, these factors do not appear to be counterbalancing the intention to leave journalism.

It's not surprising that women who intend to leave journalism are experiencing higher levels of burnout than are those intending to stay. However, those who said they intend to leave appear to be classic examples of burnout. ${ }^{79}$ After exhaustion and cynicism take hold, professional efficacy deteriorates. The women who intend to leave have reached the final stage, and because there is no clear measure for combating burnout, ${ }^{80}$ the only alternative to relieving the exhaustion and cynicism is to leave. Changing jobs or even careers might be directly associated with the uncertainty surrounding the newspaper industry. Declining advertising revenue and stock prices have led to extensive layoffs and buyouts, particularly in $2008 .^{81}$

Perhaps a more startling result is found among women who said they were not sure if they intended to leave journalism. Overall, 62 percent of women either answered "yes" or "don't know" to the question "do you have any intention of leaving newspaper journalism?" Although it wasn't specifically examined in this study, the women who answered "don't know" $(n=110)$ are suffering similar rates of burnout as those who intend to leave. Among women 27 and younger, 74.2 percent answered "yes" or "don't know" with 30.3 percent saying they intended to leave newspaper journalism.

In this study, women certainly provided distinguishing differences from men in terms of burnout and life issues that influence burnout. There are significant differences in perceived organizational support, role overload and job demands for men and women. So while women are feeling overburdened at work, which may be leading to exhaustion and reduced feelings of professional efficacy, they are not receiving the organizational support they seek. Faced with family and childcare issues, sexism, discrimination and the glass ceiling, it appears women are not receiving the organizational encouragement to contend with these issues or perhaps even to remain in journalism.

Chambers et al. wrote, 


\section{The fact that women journalists are disproportionately younger than their male counterparts suggests that they are often pressured into quitting their jobs as a result of difficulties in juggling childcare and work responsibilities. ${ }^{82}$}

This study has limitations, including the sample size. While some overall assessments can be made, applying those assessments to all female journalists is not practical without further research. Additionally, those experiencing burnout might be more apt to participate in the study than would those with lesser burnout or stress issues. Also, a survey might not be the most appropriate approach in attempting to discover the life issues that concern female journalists. Future research that includes in-depth interviews would certainly add context to this study. Additionally, pursuing the causes of stress and burnout among female journalists is fruitful ground for further exploration.

This study advances the discussion of burnout, job satisfaction and life issues that affect female journalists. It's clear that while a majority of journalism graduates are women, ${ }^{83}$ they do not feel compelled to remain in journalism. Until some of the issues in this study are addressed, women will continue to be underrepresented in newspaper newsrooms. And for those already working in newsrooms, exhaustion, cynicism and lack of efficacy could drive them out.

\section{Notes}

1. Editorial, "Should a Girl Have Brains?" Columbia Missourian, Sept. 15, 1908, 2.

2. "Journalists Will Form Press Club," Columbia Missourian, Oct. 1, 1908, 3.

3. "Newsroom employment census," ASNE. Available online at http://www.asne.org/index. cfm?id=5660. (Dec. 2, 2008).

4. David Weaver, Randal Beam, Bonnie Brownlee, Paul Voakes and G. Cleveland Wilhoit, The American Journalist in the $21^{\text {st }}$ Century: U.S. News People at the Dawn of a New Millennium (Mahwah, NJ: Lawrence Erlbaum Associates, 2007).

5. Linda Steiner, "Gender at Work: Early Accounts by Women Journalists," Journalism History 23 (spring 1997): 2-12.

6. Lee B. Becker, Tudor Vlad and Joel D. McLean, “2006 Annual Survey of Journalism \& Mass Communication Graduates." Available online at http:/ / www.grady.uga.edu/annualsurveys / Enrollment_Survey/Enrollment_2006/Enroll_2006v2.pdf. (Dec. 2, 2008).

7. "Employment Status of Women and Men in 2006," Department of Labor. Available online at http:/ / www.dol.gov/wb/ factsheets/Qf-ESWM06.htm. (Dec. 21, 2007).

8. "Employment Status of Women," Department of Labor.

9. "Newsroom employment census," ASNE. Available online at http://www.asne.org/index. cfm?id=5661. (Dec. 2, 2008).

10. Weaver et al., The American Journalist in the 21 Century; "Employment Status of Women and Men in 2006," Department of Labor.

11. Betsey Stevenson and Justin Wolfers, "The Paradox of Declining Female Happiness," Available online at http:/ / bpp.wharton.upenn.edu/betseys/ papers/Paradox $\% 20$ of $\% 20 \mathrm{declinin}$ g\%20female\%20happiness.pdf. (Dec. 2, 2008).

12. Stevenson and Wolfers, "The Paradox of Declining," 20.

13. Weaver et al., The American Journalist in the 21 Century.

14. Weaver et al., The American Journalist in the 21 Century.

15. Weaver et al., The American Journalist in the 21 Century. 
16. Weaver et al., The American Journalist in the 21 Centur. D1.

17. Frank Ahrens, "Gannett to Change Its Papers' Approach," Washington Post, Nov. 7, 2006,

18. The State of the News Media 2008: An Annual Report on American Journalism. Available onlineathttp://stateofthemedia.org/2008/narrative_newspapers_economics.php?cat=3\&media=4 (Dec. 2, 2008).

19. Erica Smith, "Paper Cuts: Layoffs and Buyouts at U.S. Newspapers." Available online at http:/ / graphicdesignr.net/papercuts/. (Dec. 2, 2008).

20. Weaver et al., The American Journalist in the 21 Century.

21. Ray Rivera, "Suit to Scrutinize Bloomberg Era at Firm," New York Times, Sept. 29, 2007, 3.

22. Deborah Chambers, Linda Steiner and Carole Fleming, Women and Journalism (New York, NY: Routledge, 2004).

23. Chambers et al., Women and Journalism, 98.

24. Christina Maslach, Susan E. Jackson and Michael P. Leiter, Maslach Burnout Inventory Manuel, 3rd edition, (Mountain View, CA: CPP, 1996); Herbert J. Freudenberger and Gail North, Women's Burnout: How to Spot It, How to Reverse It and How to Prevent it (Garden City, NY: Doubleday \& Company, 1985).

25. Thomas A. Wright and Douglas G. Bonett, "The Contribution of Burnout to Work Performance," Journal of Organizational Behavior, 18 (1997): 491-499; Thomas A. Wright and Russell Cropanzano, "Emotional Exhaustion as a Predictor of Job Performance and Voluntary Turnover," Journal of Applied Psychology, 83 (1998): 486-493; Russell Cropanzano, Deborah E. Rupp and Zinta S. Byrne, "The Relationship of Emotional Exhaustion to Work Attitudes, Job Performance and Organizational Citizenship Behaviors," Journal of Applied Psychology 88 (2003): 160-169.

26. Caren Baruch-Feldman and Joseph Schwartz, "Sources of Social Support and Burnout, Job Satisfaction and Productivity," Journal of Occupational Health Psychology 7 (2002): 84-93.

27. Richard G. Netemeyer, James S. Boles and Robert McMurrian, "Development and Validation of Work-Family Conflict and Family-Work Conflict Scales," Journal of Applied Psychology 81 (1996): 400-410.

28. Richard G. Netemeyer, Thomas Brashear-Alejandro and James S. Boles, “A Cross-National Model of Job-Related Outcomes of Work Roles and Family Role Variables: A Retail Sales Context," Academy of Marketing Science, 32 (2004): 49-60; Yueng-Hsiang Huang, Leslie B. Hammer, Margaret B. Neal and Nancy A. Perrin, "The Relationship Between Work-to-Family Conflict and Familyto-Work Conflict: A Longitudinal Study," Journal of Family and Economic Issues, 25 (2004): 79-100; Lillian T. Eby, Wendy J. Casper, Angie Lockwood, Chris Bordeaux and Andi Brinley, "Work and Family Research in IO/OB: Content Analysis and Review of the Literature (1980-2002)," Journal of Vocational Behavior 66 (2005): 124-197.

29. Centers for Disease Control. Have a Stressful Job? You Must Have an Ulcer...Right? Available online at http://www.cdc.gov/ulcer/myth.htm. (Dec. 2, 2008).

30. Bill Gloede, "Stress Has a Significant Presence in Newsrooms," Editor \& Publisher, Nov. $12,1983,12-13$.

31. Mark Fitzgerald, "Editors Under Siege: Associated Press Managing Editors Study of Stress on the Job," Editor $\mathcal{E}$ Publisher, Dec. 2, 1995, 11.

33.

32. Joanmarie Kalter, "Workplace Burnout," Columbia Journalism Review 38 (July 1999): 30-

33. Gloede, "Stress has a Significant Presence in Newsrooms;" Fitzgerald, "Editors Under Siege;" Kalter, "Workplace Burnout."

34. Julie von Onciul, "ABC of Work Related Disorders: Stress at Work," British Medical Journal, Sept. 21, 1996, 745-748.

35. Freudenberger and North, Women's Burnout, 15.

36. Maslach, Jackson and Leiter, Maslach Burnout Inventory Manuel.

37. Christina Maslach and Susan E. Jackson, "The Measurement of Experienced Burnout," 
Journal of Occupational Behaviour, 2 (April 1981): 99-113.

38. Maslach, Jackson and Leiter, Maslach Burnout Inventory Manuel, 20.

39. Wilmar Schaufeli and Dirk Enzmann. The Burnout Companion to Study \& Practice: A Critical Analysis (London: Taylor \& Francis, 1998).

40. Schaufeli and Enzmann, The Burnout Companion to Study \& Practice.

41. Schaufeli and Enzmann, The Burnout Companion to Study \& Practice, 7.

42. Maslach, Jackson and Leiter, Maslach Burnout Inventory Manuel, 20.

43. Maslach, Jackson and Leiter, Maslach Burnout Inventory Manuel.

44. Maslach, Jackson and Leiter, Maslach Burnout Inventory Manuel.

45. Maslach and Jackson, "The Measurement of Experienced Burnout," 99.

46. Maslach, Schaufeli and Leiter, "Job Burnout," 399.

47. Scott Reinardy, "It's Gametime: The Maslach Burnout Inventory measures burnout of sports journalists," Journalism \& Mass Communication Quarterly, 83 (summer 2006): 397-412; Betsy B. Cook and Steven R. Banks, "Predictors of Job Burnout in Reporters and Copy Editors," Journalism Quarterly 70 (spring 1993): 108-116; Betsy B. Cook, Steve R. Banks and Ralph J. Turner, "The Effects of Work Environment on Burnout in the Newsroom," Newspaper Research Journal 14 (summer/fall 1993): 123-136.

48. Cook and Banks, "Predictors of Job Burnout."

49. Reinardy, "It's Gametime."

50. Christine Doyle and Patricia Hind, "Occupational Stress, Burnout and Job Status in Female Academics," Gender, Work and Organization, 5 (April 1997): 67-82. 74

51. Doyle and Hind, "Occupational Stress, Burnout and Job Status," 74.

52. Doyle and Hind, "Occupational Stress, Burnout and Job Status."

53. Doyle and Hind, "Occupational Stress, Burnout and Job Status," 79.

54. Esther R. Greenglass, Ronald J. Burke and Roman Konarski, "Components of Burnout, Resources and Gender-Related Differences," Journal of Applied Social Psychology, 28 (June 1998): 1088-1106; Amanda C. Weckwerth and Deborah M. Flynn, "Effect of Sex on Perceived Support and Burnout in University Students," College Student Journal, 40 (June 2006): 237-249; Hans Te Brake, Anne-Marthe Bouman, Ronald Gorter, Johan Hoogstraten and Michiel Eijkman, "Professional Burnout and Work Engagement among Dentists," European Journal of Oral Science, 115 (June 2007): $180-185$.

55. Weckwerth and Flynn, "Effect of Sex."

56. Greenglass, Burke and Konarski, "Components of Burnout;" Marrie H.J. Bekker, Marcel A. Croon, Bibi Bressers, "Childcare Involvement, Job Characteristics, Gender and Work Attitudes as Predictors of Emotional Exhaustion and Sickness Absence," Work \& Stress, 13 (July 2005): 221-237; Kirsi Ahola, Teija Honkonen, Erkki Isometsa, Raija Kalimo, Erkki Nykyri, Seppo Koskinen, Arpo Aromaa and Jouko Lonnqvist, "Burnout in the General Population: Results From the Finnish Health 2000 Study," Social Psychiatry and Psychiatric Epidemiology, 41 (January 2006): 11-17.

57. Bekker et al., "Childcare Involvement."

58. Ahola et al., "Burnout in the General Population."

59. Greenglass et al., "Components of Burnout."

60. Cortlandt Cammann, Mark Fichman, G. Douglas Jenkins Jr. and John R. Klesh, "Assessing the Attitudes and Perceptions of Organizational Members," in Assessing Organizational Change: A Guide to Methods, Measures and Practices, ed. Stanley E. Seashore, Edward E. Lawler III, Philip H. Mirvis and Cortlandt Cammann (NY: John Wiley \& Sons, 1983), 71-138.

61. Cammann et al., "Assessing Organizational Change," 80.

62. Robert Eisenberger, Robin Huntington, Steven Hutchison and Debora Sowa, "Perceived Organizational Support," Journal of Applied Psychology 71 (1986): 500-507.

63. Linda Rhoades and Robert Eisenberger, "Perceived Organizational Support: A Review of the Literature," Journal of Applied Psychology, 87 (2002): 698-714.

64. Richard G. Netemeyer, James S. Boles and Robert McMurrian, "Development and Valida- 
tion of Work-Family Conflict and Family-Work Conflict Scales," Journal of Applied Psychology 81 (1996): 400-410.

65. Netemeyer et al., "Development and Validation," 401.

66. Eby, Casper, Lockwood, Bordeaux and Brinley, "Work and Family Research;" Huang, Hammer, Neal and Perrin, "The Relationship Between Work-to-Family Conflict;" Ellen Ernst Kossek and Cynthia Ozeki, "Work-Family Conflict, Policies and the Job-Life Satisfaction Relationship: A Review and Directions for Organizational Behavior-Human Resources Research," Journal of Applied Psychology 83 (1998): 139-149; Netemeyer, Boles and McMurrian, "Development and Validation of Work-Family Conflict;" Richard G. Netemeyer, R.G., Thomas Brashear-Alejandro and James S. Boles, "A Cross-National Model of Job-Related Outcomes of Work Roles and Family Role Variables: A retail sales context," Academy of Marketing Science, 32 (2004): 49-60; Michael Simon, Angelika Kummerling and Hans-Martin Hasselhorn, "Work-Home Conflict in the European Nursing Profession," International Journal of Occupational and Environmental Health, 10 (2004): 384-391.

67. Terry A. Beehr, Jeffrey T. Walsh and Thomas D. Taber, "Relationship of Stress to Individually and Organizationally Valued States: Higher Order Needs as a Moderator," Journal of Applied Psychology 61 (February 1976): 41-47.

68. Samuel B. Bacharach, Peter Bamberger and Sharon C. Conley, "Work Processes, Role Conflict and Role Overload: The Case of Nurses and Engineers in the Public Sector," Work and Occupations 17 (May 1990): 199-228. 202.

69. Bacharach, Bamberger and Conley, "Work Processes, Role Conflict and Role Overload,"

70. Robert A. Karasek Jr., "Job Demands, Job Decision Latitude and Mental Strain: Implications for Job Redesign," Administrative Science Quarterly, 24 (June 1979): 285-308.

71. 2006 Editor \& Publisher International Year Book (NY: Editor \& Publisher Co., 2006).

72. Scott Reinardy, "It's Gametime: The Maslach Burnout Inventory Measures Burnout of Sports Journalists," Journalism \& Mass Communication Quarterly 83 (summer 2006): 397-412; Matthias Schonlau, Ronald D. Fricker Jr. and Marc N. Elliott, Conducting Research Survey Via E-mail and the Web (Santa Monica, CA: Rand, 2002); Roger D. Wimmer and Joseph R. Dominick, Mass media research: An introduction, 8th edition, (Belmont, CA: Thomson Higher Education, 2006).

73. Bekker et al., "Childcare Involvement; "Ahola et al., "Burnout in the General Population."

74. Weckwerth and Flynn, "Effect of Sex."

75. Maslach, Jackson and Leiter, Maslach Burnout Inventory Manuel, 21.

76. Maslach, Schaufeli and Leiter, "Job Burnout."

77. Barbara M. Byrne, "Burnout: Testing for the Validity, Replication and Invariance of Causal Structure Across Elementary, Intermediate and Secondary Teachers," American Educational Research Journal, 31 (fall 1994): 645-673; Michael P. Leiter, "Burnout as a developmental process: Consideration of models," in Professional Burnout: Recent Developments in Theory and Research, ed. Wilmar B. Schaufeli, Christina Maslach and Tadeusz Marek (Washington D.C.: Taylor \& Francis, 1993), 237250; Raymond T. Lee and Blake E. Ashforth, "A Meta-Analytic Examination of the Correlates of the Three Dimensions of Job Burnout," Journal of Applied Psychology, 81 (April 1996): 123-133.

78. Lee and Ashforth, "A Meta-Analytic Examination," 128.

79. Maslach, Schaufeli and Leiter, "Job Burnout."

80. Maslach, Schaufeli and Leiter, "Job Burnout."

81. "The State of the News Media 2008," 2008; "Financial Woes Now Overshadow all Other Concerns for Journalists," The Pew Research Center. Available online at: http:/ / people-press.org/reports / display.php3?ReportID=403. Retrieved December 2, 2008; “Paper Cuts: Newspaper Buyouts and Layoffs," 2008.

82. Chambers et al., Women and Journalism, 102.

83. Becker et al., "2006 Annual Survey of Journalism." 
Copyright of Newspaper Research Journal is the property of Newspaper Research Journal and its content may not be copied or emailed to multiple sites or posted to a listserv without the copyright holder's express written permission. However, users may print, download, or email articles for individual use. 